\title{
Cash Management in Cameo Corporate Services Limited
}

\author{
J.Pavithra, R.Ramamoorthy, Prasath Alias Surendhar
}

\begin{abstract}
The term cash management refers to the management of cash resource in such a way that generally accepted business objectives could be achieved. In this context, the objectives of a firm can be unified as bringing about consistency between maximum possible profitability and liquidity of a firm. Cash management may be defined as the ability of a management in recognizing the problems related with cash which may come across in future course of action, finding appropriate solution to curb such problems if they arise, and finally delegating these solutions to the competent authority for carrying them out The choice between liquidity and ij profitability creates a state of confusion. It is cash management that can provide solution to this dilemma.Cash management may be regarded as an art that assists in establishing equilibrium between liquidity and profitability to ensure undisturbed functioning of a firm towards attaining its li business objectives[1],[3],[5]

Keywords : Cash,cameo,cash flow
\end{abstract}

\section{INTRODUCTION}

Coins is an important modern-day asset for the operation of the business. coins is the fundamental enter needed to preserve the commercial enterprise walking on a continuation foundation. it's also the remaining output found out by using selling the services or product manufactured by means of the company. coins is the most liquid of all the current belongings. higher cash and financial institution balance suggest high liquidity position in lower profitability, as best cash fetches no return. consequently a first-rate feature of finance supervisor is preserve sound cash position. [7],[ 9], [11]

cash is the money which a firm can disburse right now with none restriction. The term cash includes coins, forex and cheques held by means of the firm, and balances in its bank money owed. occasionally close to-cash items, inclusive of marketable securities or financial institution times deposits, are also covered in coins. The primary function of close to-cash property is that they can with no trouble be transformed into coins. typically, when a company has excess cash, it invests it in marketable securities. This sort of investment contributes some profit to the company. [8],[10] ,[12]

Revised Manuscript Received on July 22, 2019.

J.Pavithra, Department of MBA, Bharath Institute of Higher Education and Research, Tamilnadu, India. Email: pavithralect@yahoo.com

R.Ramamoorthy, Department of MBA, Bharath Institute of Higher Education and Research, Tamilnadu, India. Email: ramamoorthy0071@gmail.com

Prasath Alias Surendhar, Department of Biomedical engineering, Bharath Institute of Higher Education and Research, Tamilnadu, India. Email: mail.surendhar@gmail.com

\section{OBJECTIVES}

The reason of preparing a cash flow projection is to decide shortages or excesses in cash from that necessary to operate the enterprise in the course of the time for which the projection is ready. [2 ],[ 4],[6]

- If cash shortages are found out inside the mission, financial plans should be altered to offer extra coins until a right cash flow balance is acquired

- approaches to lessen the amount of cash paid out consists of having less stock, decreasing purchases of device or different constant belongings, or doing away with a few operating charges.

- If excesses of coins are found out, it would indicate immoderate borrowing or idle money that could be "placed to paintings." The objective is to finally expand a plan which, if followed, will provide a properly-controlled float of coins.

\section{SCOPE OF THE STUDY}

The purpose of preparing a cash flow project is to determine shortages or excesses in cash.

- approaches to reduce the quantity of coins paid out includes having fewer inventories, decreasing purchases of gadget or other constant property, or getting rid of some working charges.

- The objective is to ultimately increase a plan which, if followed, will provide a well- managed go with the flow of cash.

- It entails the observe of the present pattern of coins flow management in the organization.

- recognize the forms of transactions that bring about cash flows from running, making an investment, and financing activities.

- To understand the monetary soundness of the enterprise.

- develop an ability to research the announcement of projected coins flows, which includes the relation amongst cash flows from operating, making an investment, and financing activities for businesses in diverse ranges of their growth.

\section{RESEARCH METHODLOGY}

A.Primary Data:

Number one records is amassed with consultation and dialogue with the involved body of workers. The agency every time calls for finances they arrange the finances from the internal resources. They set up the finances from purchaser strengthen. The employer broadly speaking does no longer borrow budget from the banks. 


\section{Cash Management in Cameo Corporate Services Limited}

each time the business enterprise gets the cash from the borrowers they simultaneously pay to their lenders. The agency has proper balances among the inflow and outflow of the funds thru the debtors and lenders.

those encompass the survey or questionnaire method, in addition to the private interview methods of records collection. [13], [15] ,[ 17]

\section{B. RESEARCH DESIGN}

The design for this study is basically analytical because it utilize the large number of data of the Company

Sample size: 100

C. TYPE OF SAMPLE

Sampling refers to the technique of selecting a pattern from a given universe so that you can draw conclusions about that universe. A pattern is a representative of the universe decided on for take a look at[14],[ 16], [18]

D.Secondary Data:

It became amassed from the $\mathrm{P} \& \mathrm{~L} \mathrm{~A} / \mathrm{c}$, balance sheet, reference books based totally on monetary control \& management accounting. The various books helped in know-how the diverse theoretical standards associated with the project inclusive of the significance of cash go with the flow control \& the way to interpret diverse budget. all of the figures required to carry out the ratio analysis were accumulated from financial statements together with P\&L A/c, stability sheet of the enterprise

- $\quad$ statistics amassed from contributors of Cameo Ltd.

- records amassed via questionnaires.

- records accumulated via telephonic communique.

- facts accrued from diverse books.

- data accrued from internet

\section{V.TOOLS OF DATA ANALYSIS}

Since the analysis was of the various cash flow activities, the important tool of data analysis are cash flow statement and ratio analysis. Tables and graphs were prepared to have a clear understandings of the subject, the tables were put into graphs to make more understandable[20],[ 22], [24]

Do you have a spending plan or budget?

\begin{tabular}{|l|l|}
\hline Options & Responds \\
\hline Yes & 90 \\
\hline NO & 8 \\
\hline Don't know & 2 \\
\hline
\end{tabular}

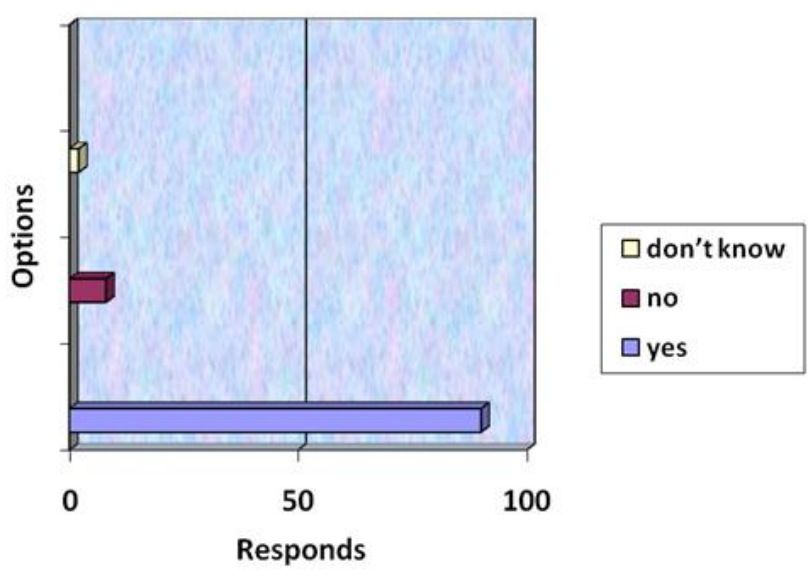

\section{INTERPRETATION}

in the above chart display the respondents have showed the very best reaction on yes that means the company has the stable and efficient price range and spending plan to make powerful coins waft and eight of the human beings says that No on the way to affect the company any more and 2 of the human beings says dint know as a way to now not take as the principle attention, So the company have the effective spending plan. [19],[21],[23]

Do you monitor your expenses?

\begin{tabular}{|l|l|}
\hline Options & Responds \\
\hline Yes & 85 \\
\hline NO & 10 \\
\hline Don't know & 5 \\
\hline
\end{tabular}

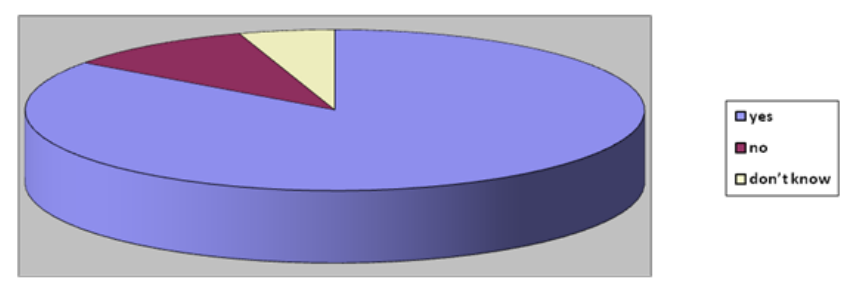

\section{INTERPRETATION}

it is very crucial to any company that video display units the charges to control the coins outflow inside the enterprise. within the chart indicates the maximum of the respondents this is $85 \%$ of the human beings are said that the business enterprise display their costs that indicates the agency coins drift inside the appropriate position and the opposite says 10 of No and 5 don't realize this could no longer affect the agencies glide due to the fact the most of the people voted as sure. [25],[27],[29]

Is your cash flow positive? 


\begin{tabular}{|l|l|}
\hline Options & Responds \\
\hline Yes & 91 \\
\hline NO & 4 \\
\hline Don't know & 5 \\
\hline
\end{tabular}

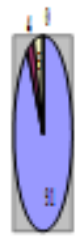

\section{INTERPRETATION}

This is the main question that corporation wishes to recognize that the coins go with the flow of the agency is advantageous or negative the primary variety of the said that the coins flow is positive i.e., ninety one, the alternative humans says no and don't realize in an effort to harm the agency proceedings therefore their specialists in their organization gives their solutions. From the above diagram indicates the employer coins flow is in higher position[26],[28],[30]

Are you saving enough for future funding requirements

\begin{tabular}{|l|l|}
\hline Options & Responds \\
\hline Yes & 80 \\
\hline NO & 15 \\
\hline Don't know & 5 \\
\hline
\end{tabular}

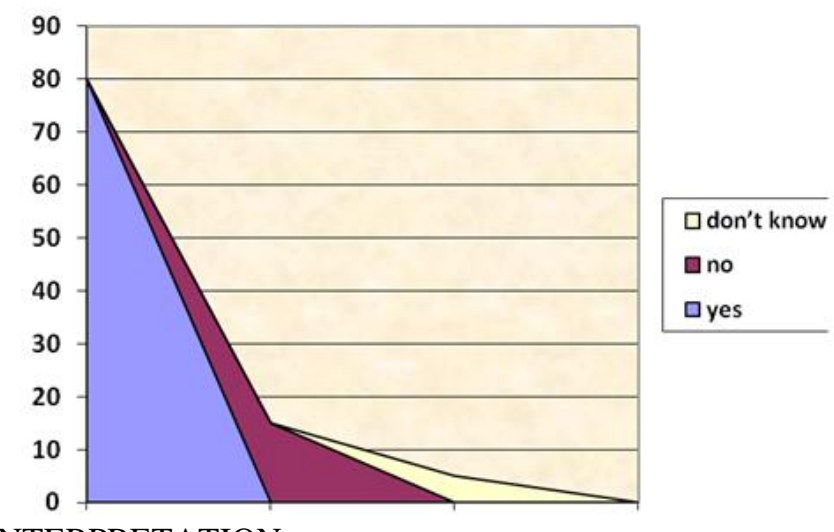

\section{INTERPRETATION}

Being from the balance sheet and profit and loss account statement says that the cash balances even though the question asked to the management people that the results also the same, the fund for the future requirements is enough saying that $80 \%$ of the people, the others are said 15 to the No and 5 to the don't know that will not affect the company growth

\section{RESULTS}

1.) In cameo corporate services maintains the effective cash flow so there is good possibilities for the future development.

2.) The financial experts of this have very keen to plan a budget in any other company and they spend lot of time on it so the finance should be very effective.

3.) The company assigned themselves the good financial goals and they follow it very effectively so there is expenses are monitored effectively.

4.) The financial systems are centralised in the company so the everyone in the company can know the company where its stands.

5.) The financial reports are used by the management frequently so that the know how to monitor the expenses and income of the company and they budget accordingly.

6.) Company manages its cash well and spending large amount of funds for its cash management system.

7.) Company is investing its funds in long term investments which will be helpful to the company for long further growth.

8.) Company is on growth and there is further scope of future growth.

9) In the cash flow statement shows the frequent growth of the cash in each year that shows the company in the good position.

10.) Net working capital also shows the good results.

\section{DISCUSSION}

1.) Enterprise can review present provider vendors for cash control and other carrier providers, making initial displays and discussions with banks and carriers. businesses can shortlist ability carriers for similarly in-intensity discussions and displays. It enables in lowering wearing cost of coins. [31],[33],[32]

2.) Organisation can invest idle price range accurately can also assist you to generate income out of your running capital, increasing your yields at the same time as preserving liquidity. There are a huge style of investment devices available to corporations searching for a go back on excess coins. but, there are ways enterprise may be capable of enhance yields on our idle operating capital.

3.) For better cash control or so as to find minimal cash stability required for the organization can use manage charts with the help of this business enterprise will capable of make investments its extra amount of price range in short time period securities and might lessen financial institution prices charged through the financial institution for overdraft cause.

4.) Agency goes in the right path, in the event that they maintain the identical degree and enhance the 


\section{Cash Management in Cameo Corporate Services Limited}

contemporary degree scope for the further development for the future.

five.) company is on boom and there's scope for further scope

\section{CONCLUSION}

The coins waft assertion shows that internet growth in cash generated from working and financing activities is a lot more than the previous yr however coins from investing activities is poor in each yr. there is boom of Rs.851324604. in increase in coins \& coins equivalents from previous year. therefore evaluation of coins waft statement indicates that cash inflow is greater than the cash outflow in CAMEO LTD.The organization's usual function is at a great position. specifically the modern-day yr's role is properly due to raise inside the earnings degree from the ultimate yr role. it's miles higher for the organisation to diversify the budget to one-of-a-kind sectors within the present market situation

\section{REFERENCES}

1. G BharthVajan R., Ramachandran S.,Psychographic dimensions of training,2016,International Journal of Pharmacy and Technology,V-8,I-4,P-23727-23729

2. Balakrishnan P., Bharthvajan R.,A study on human resource planning in hospitals in Chennai City,2014,International Journal of Applied Engineering Research,V-9,I-22,P-7503-7507

3. Priyadarsini P., Bharthvajan R.,Role of emotional intelligence training programme in reducing the stress of the nurses,2014,International Journa of Applied Engineering Research,V-9,I-22,P-7411-7421

4. Kerinab Beenu G., Bharthvajan R.,Empirical analysis on the cosmetic buying behavior of young women in South India,2014,International Journal of Applied Engineering Research,V-9,I-22,P-7361-7366

5. Balakrishnan P., Bharthvajan R.,Whistling in the wind,2014,International Journal of Applied Engineering Research,V-9,I-22,P-7586-7593

6. Krishnan B., Peter M.,Health hazards of Indian Bpo employee-an alarming issue,2014,International Journal of Applied Engineering Research,V-9,I-22,P-7336-7341

7. Kerinab Beenu G.H., Peter M.,Role of insurance in economic development,2014,International Journal of Applied Engineering Research,V-9,I-22,P-7532-7539

8. Balakrishnan P., Peter M., Priyadarsini P.,Efficiency of safety measures for wellbeing of employees in manufacturing industry,2014,International Journal of Applied Engineering Research,V-9,I-22,P-7376-7382

9. Anbarasi M., Praveen Kumar S.,Online sales promotions of herbal products and its effectiveness towards tanisha.com,2019,Indian Journal of Public Health Research and Development,V-10,I-1,P-195-200

10. Anbarasi M., Praveen Kumar S.,Various online marketing and promotions strategies to improve the validation towards the organic products in the pharmaceutical sectors,2019,Indian Journal of Public Health Research and Development,V-10,I-1,P-263-269

11. Loganathan R., Praveen Kumar S.,Grievance handling a key factor for solving issues of employees in an organization,2014,International Journal of Applied Engineering Research,V-9,I-22,P-7483-7491

12. Loganathan R., Praveen Kumar S.,Study on preference of private label brands in super and Hypermarkets, 2014,International Journal of Applied Engineering Research,V-9,I-22,P-7327-7335

13. Smitha M., Praveen Kumar S.,Understanding stress and its managementamong the nurses in Chennai city,2014,International Journal of Applied Engineering Research,V-9,I-22,P-7560-7565

14. Kerinab Beenu G.H., Praveen Kumar S.,A study on the investment behavior of Chennai investors in mutual fund schemes,2014,International Journal of Applied Engineering Research,V-9,I-22,P-7520-7525

15. Loganathan R., Praveen Kumar S.,Retention strategies key for organizational productivity,2014,International Journal of Applied Engineering Research,V-9,I-22,P-7443-7447

16. Pavithra J., Ganesan M., Brindha G.,State wise analysis of microfinance sector in India,2016,International Journal of Pharmacy and Technology,V-8,I-4,P-23417-23432

17. Pavithra J., Ganesan M.,A comparative study on microfinance in India and abroad,2016,International Journal of Applied Business and Economic Research,V-14,I-8,P-5471-5476

18. Pavithra J., Ganesan M.,A study on awareness and impact of micro-financial schemes,2016,International Journal of Applied Business and Economic Research,V-14,I-8,P-5449-5460
19. Senthilmurugan P., Pavithra J.,Consumer preference towards organised retailing with reference to Big Bazaar,2014,International Journal of Applied Engineering Research,V-9,I-22,P-7469-7475

20. Senthilmurugan P., Pavithra J.,Implication of social media marketing in growing healthcare industry,2014,International Journal of Applied Engineering Research,V-9,I-22,P-7448-7456

21. Loganathan R., Pavithra J.,Consumer perception towards private label brand over other brands in super markets and hypermarkets,2014,International Journal of Applied Engineering Research,V-9,I-22,P-7355-7360

22. Kerinab Beenu G., Pavithra J.,Tradeâ€"off between liquidity and profitability in logistics industry,2014,International Journal of Applied Engineering Research,V-9,I-22,P-7398-7401

23. Kerinab Beenu G., Pavithra J.,A study on the prospective consumerâ $€^{\mathrm{TM}_{\mathrm{S}}}$ perception towards utility cars in Chennai city,2014,International Journal of Applied Engineering Research,V-9,I-22,P-7526-7531

24. Pavithra J., Dilli Babu P., Ambuli T.V.,A study on budgetary control at Maruti Service Masters, Chennai,2014,International Journal of Applied Business and Economic Research,V-12,I-2,P-151-161

25. Pavithra J., Dilli Babu P., Ambuli T.V.,A study on customer satisfaction of retro Garments Pvt Ltd, Chennai,2014,International Journal of Applied Business and Economic Research,V-12,I-2,P-381-391

26. Kerinab Beenu G.H., Pavithra J., Senthilmurugan P.,A study on the influence of promotional activities for TATA ARIA among consumers in Chennai,2014,International Journal of Applied Engineering Research,V-9,I-22,P-7572-7578

27. Vijayaragavan S.P.,An investigative expert that's general FBG sensors, International Journal of Mechanical Engineering and Technology,V-8,I-8,PP-1500-1505,Y-2017

28. Vijayaragavan S.P.,Equalization routing protocol for Wi-Fi sensor strategy,International Journal of Mechanical Engineering and Technology,V-8,I-8,PP-1662-1666,Y-2017

29. Karthik B., Kiran Kumar T.V.U., Vijayaragavan P., Bharath Kumaran E.,Design of a digital PLL using 0.35 $\hat{\mathrm{I}}^{1 / 4} \mathrm{~m}$ CMOS technology,Middle East Journal of Scientific Research,V-18,I-12,PP-1803-1806,Y-2013

30. Kanniga E., Selvaramarathnam K., Sundararajan M.,Kandigital bike operating system,Middle - East Journal of Scientific Research,V

31. Jasmin M., Vigneshwaran T., Beulah Hemalatha S.,Design of power aware on chip embedded memory based FSM encoding in FPGA,International Journal of Applied Engineering Research,V-10,I-2,PP-4487-4496,Y-2015

32. Jasmin M.,Optimization techniques for low power VLSI circuits,Middle East Journal of Scientific Research,V-20,I-9,PP-1082-1087,Y-2014

33. Jasmin M., Vigneswaran T.,Fuzzy controller for error control of on - Chip communication,2017 International Conference on Algorithms, Methodology, Models and Applications in Emerging Technologies, ICAMMAET 2017,V-2017-January,I-,PP-1-5,Y-2017

\section{AUTHORS PROFILE}

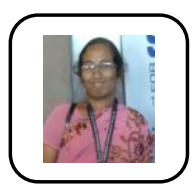

J.Pavithra Assistant Professor ,Department of MBA Bharath Institute of Higher Education and Research, Tamilnadu, India

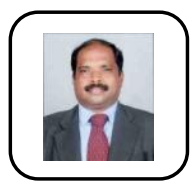

R.Ramamoorthy Assistant Professor, Department of MBA, Bharath Institute of Higher Education and Research, Tamilnadu, India

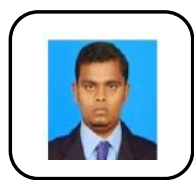

Prasath Alias Surendhar Assistant Professor ,Department of Biomedical engineering, Bharath Institute of Higher Education and Research, Tamilnadu, India 